\title{
Modelling the mid-Pliocene Warm Period climate with the IPSL coupled model and its atmospheric component LMDZ5A
}

\author{
C. Contoux ${ }^{1,2}$, G. Ramstein ${ }^{1}$, and A. Jost ${ }^{2}$ \\ ${ }^{1}$ Laboratoire des Sciences du Climat et de l'Environnement/IPSL, CEA-CNRS-UVSQ, UMR8212, Orme des Merisiers, \\ CE Saclay, 91191 Gif-sur-Yvette Cedex, France \\ ${ }^{2}$ Université Pierre et Marie Curie \& CNRS, UMR7619, Sisyphe, Case 123, 4 place Jussieu, 75252 Paris Cedex 05, France \\ Correspondence to: C. Contoux (camille.contoux@1sce.ipsl.fr)
}

Received: 31 January 2012 - Published in Geosci. Model Dev. Discuss.: 17 February 2012

Revised: 23 May 2012 - Accepted: 30 May 2012 - Published: 28 June 2012

\begin{abstract}
This paper describes the experimental design and model results of the climate simulations of the mid-Pliocene Warm Period (mPWP, ca. 3.3-3 Ma) using the Institut Pierre Simon Laplace model (IPSLCM5A), in the framework of the Pliocene Model Intercomparison Project (PlioMIP). We use the IPSL atmosphere ocean general circulation model (AOGCM), and its atmospheric component alone (AGCM), to simulate the climate of the mPWP. Boundary conditions such as sea surface temperatures (SSTs), topography, ice-sheet extent and vegetation are derived from the ones imposed by the Pliocene Model Intercomparison Project (PlioMIP), described in Haywood et al. (2010, 2011). We first describe the IPSL model main features, and then give a full description of the boundary conditions used for atmospheric model and coupled model experiments. The climatic outputs of the mPWP simulations are detailed and compared to the corresponding control simulations. The simulated warming relative to the control simulation is $1.94^{\circ} \mathrm{C}$ in the atmospheric and $2.07^{\circ} \mathrm{C}$ in the coupled model experiments. In both experiments, warming is larger at high latitudes. Mechanisms governing the simulated precipitation patterns are different in the coupled model than in the atmospheric model alone, because of the reduced gradients in imposed SSTs, which impacts the Hadley and Walker circulations. In addition, a sensitivity test to the change of landsea mask in the atmospheric model, representing a sea-level change from present-day to $25 \mathrm{~m}$ higher during the midPliocene, is described. We find that surface temperature differences can be large (several degrees Celsius) but are restricted to the areas that were changed from ocean to land or vice versa. In terms of precipitation, impact on polar regions
\end{abstract}

is minor although the change in land-sea mask is significant in these areas.

\section{Introduction}

The mid-Pliocene Warm Period (mPWP, ca. 3.3-3 Ma) is the most recent period in geological history when Earth experienced a warmer climate than the preindustrial during a sustained period of time, longer than interglacial periods of the last million years. Moreover, the mPWP being a quite recent period at the geological scale, continents position is similar to the present one, and the $\mathrm{CO}_{2}$ content is very close to present-day one $(405 \mathrm{ppm})$, both conditions making the mPWP a relevant analogue for future global warming. Nevertheless, it must be kept in mind that the mPWP climate is simulated in equilibrium with prescribed boundary conditions whereas the future climate will be very far from equilibrium due to a rapid increase of forcings (Crowley, 1991). One issue is to assess whether or not climate models are able to reproduce a warmer than today climate, and to determine model biases (Crowley, 1996; Salzmann et al., 2009). Availability of data generally decreases when one goes back in time, but the mPWP being a quite recent period and also a sustained one $(\sim 300000 \mathrm{yr})$, numerous terrestrial and marine records are available (e.g. Dowsett et al., 1999; Robinson et al., 2008; Salzmann et al., 2008; Dowsett et al., 2009), and made it possible to build datasets that are used for deriving vegetation and sea surface temperatures (SSTs). These databases include a large quantity of data and allow a more accurate interpretation of the mPWP climate. They are now 
at a global level that enables comparison with model results. On their side modellers show increased interest in simulating the mPWP. Since the Piacenzian period is globally warmer than any interglacial, and occurred just before the onset of Northern Hemisphere Glaciation and the glacial-interglacial driven climates, it is certainly an interesting target for paleoclimate modellers. After the pioneering simulations performed by Chandler et al. (1994), Sloan et al. (1996) and Haywood et al. (2000), it is now a large group who shares similar boundary conditions thanks to the PlioMIP initiative, in order to compare model results. This aspect makes it important to document each group's implementation of boundary conditions, models and their basic results. We present simulations of the mid-Pliocene climate carried out with the atmosphere-ocean general circulation model (AOGCM) of the Institut Pierre Simon Laplace (IPSL), and with its atmospheric component alone (AGCM). The boundary conditions used are the ones used in the PlioMIP framework (Haywood et al., 2010, 2011). We also present a sensitivity test to the change of the land-sea mask in the atmospheric model, representing a $25 \mathrm{~m}$ sea-level rise.

\section{Model description}

The coupled atmosphere-ocean general circulation model (AOGCM) used in this study is IPSLCM5A, which is a higher resolution version of the IPSLCM4 coupled atmosphere-ocean GCM (Marti et al., 2010) that was previously used for CMIP3/IPCC AR4 (Dufresne et al., 2005). A detailed description of the different components can be found in Dufresne et al. (2012). The different components of the model i.e. atmosphere, land surface, ocean and sea-ice are also shortly detailed in the following. All these components are coupled via the OASIS coupler (Valcke, 2006). For the atmosphere-only simulations (AGCM), the ocean and sea-ice components are not used, SSTs and sea-ice are imposed.

\subsection{LMDZ5A atmosphere model}

The following description of the LMDZ model is based on Hourdin et al. (2006) and Hourdin et al. (2012). Details about the physical parametrisation can be found in Hourdin et al. (2006). LMDZ is the climate model developed at Laboratoire de Météorologie Dynamique, in Paris. This model has the specificity to be zoomed (the $\mathrm{Z}$ of LMDZ) if necessary on a specific region and then may be used for regional studies (e.g., Jost et al., 2009). Atmosphere dynamics are represented by a finite-difference discretisation of the primitive equations of meteorology (e.g., Sadourny and Laval, 1984) on a longitude-latitude Arakawa C-grid (e.g., Kasahara, 1977). The chosen resolution of the model is $96 \times 95 \times 39$, corresponding to an interval of 3.75 degrees in longitude and 1.9 degrees in latitude. There are 39 vertical levels, with around 15 levels above $20 \mathrm{~km}$, its resolution in the stratosphere being close to a previous stratospheric version of LMDZ4 described by Lott et al. (2005). A leapfrog scheme is used for time integration. The Morcrette (1991) scheme is used for radiative transfer. Effects of the subgrid scale orography are parametrised according to Lott (1999).

\subsection{ORCHIDEE land surface model}

ORCHIDEE (Organizing Carbon and Hydrology In Dynamic Ecosystems, Krinner et al., 2005) is composed of three modules: hydrology, carbon cycle and vegetation dynamics. The hydrological module, SECHIBA (Ducoudré et al., 1993; de Rosnay and Polcher, 1998), describes exchange of energy and water between atmosphere and biosphere, and the soil water budget (Krinner et al., 2005). The river routing scheme combines the river flow with a cascade of three reservoirs: the stream and two soil reservoirs with different time constants (Marti et al., 2010). Vegetation dynamics parametrisation is derived from the dynamic global vegetation model LPJ (Sitch et al., 2003; Krinner et al., 2005). The carbon cycle model simulates phenology and carbon dynamics of the terrestrial biosphere (Krinner et al., 2005). Vegetation distributions are described using 13 plant functional types (PFTs) including agricultural $\mathrm{C} 3$ and $\mathrm{C} 4$ plants, which are not used in the mPWP simulations, bringing down the number of PFTs to 11 , including bare soil. In our case, hydrology and carbon modules are activated, but vegetation is prescribed, using 11 PFTs, derived from the PRISM3 vegetation dataset (Salzmann et al., 2008). Therefore, soil, litter, and vegetation carbon pools (including leaf mass and thus LAI) are calculated as a function of dynamic carbon allocation (Krinner et al., 2005).

\subsection{NEMO ocean model}

The ocean model version is NEMOv3.2 (Nucleus for European Modelling of the Ocean, Madec, 2008), used with a resolution of $182 \times 149 \times 31$. We summarize here the main characteristics of the model as described by Marti et al. (2010). Details of the ocean physics and boundary conditions can be found in Madec et al. (1997). The ocean configuration ORCA2.3 uses a tripolar grid with horizontal curvilinear mesh (Madec and Imbard, 1996; Murray, 1996), with two poles in the Northern Hemisphere, over Canada and Siberia, to overcome the North Pole singularity. Mean grid spacing is about 2 degrees. Latitudinal resolution is refined to 0.5 degree near the equator and 1 degree in the Mediterranean Sea. The Gibraltar Strait has a width of $111 \mathrm{~km}$, and is explicitly resolved. There are 31 vertical levels in the ocean, with 10 levels in the top $100 \mathrm{~m}$. A total variance dissipation scheme is used for advection of temperature and salinity (Lévy et al., 2001; Cravatte et al., 2007). A conservation scheme of both energy and enstrophy is used in the momentum equation (Arakawa and Lamb, 1981; Le Sommer et al., 2009). 

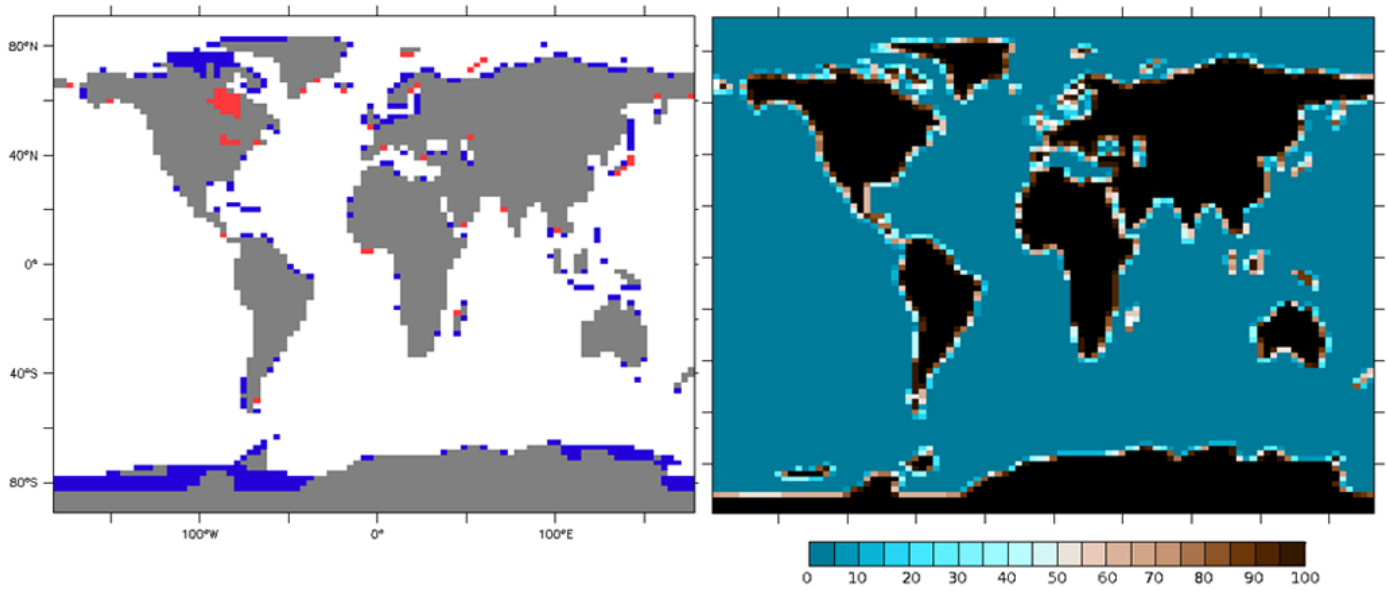

Fig. 1. Difference between present land-sea mask and mPWP land-sea mask (left). Blue grid cells are land in the present mask (i.e. land fraction superior or equal to $50 \%$ ), but ocean in the mPWP mask. Red grid cells are ocean in the present mask and land in the mPWP mask. Land percentage on each grid cell for the "preferred" simulation (right).

\subsection{LIM sea-ice model}

The sea-ice model used is LIM2 (Louvain-la-Neuve Sea Ice Model), a thermodynamic-dynamic sea-ice model described in Fichefet and Morales-Maqueda (1997, 1999). We present here the main features of the model as described in the latter paper (Fichefet and Morales-Maqueda, 1999). A three-layer model determines vertical heat conduction and sensible heat storage inside ice and snow. There is one layer for snow and two layers for ice. Trapping of shortwave radiation by brine pockets resulting in latent heat storage inside the ice is taken into account. The model also allows for the presence of leads within the ice pack. Vertical and lateral growth/decay rates are obtained from the prognostic energy budgets at both the bottom and surface boundaries of the snow-ice cover and in leads. Surface albedo is parametrised as a function of surface temperature and of snow and ice thicknesses. LIM runs on the same grid than NEMO (Marti et al., 2010).

\section{Experimental design}

\subsection{Pre-industrial}

For the AGCM experiments, the control simulation boundary conditions (i.e. SSTs, vegetation, topography and icesheet extents) are set to modern. Imposed SSTs are the mean value for 1988-2007. Greenhouse gases, solar constant and orbital parameters are set to Pre-industrial values as required by CMIP5/PMIP3, i.e. solar constant is $1365 \mathrm{~W} \mathrm{~m}^{-2}, \mathrm{CO}_{2}$ content is $280 \mathrm{ppm}, \mathrm{CH}_{4}$ content is $760 \mathrm{ppb}$, and $\mathrm{N}_{2} \mathrm{O}$ content is $270 \mathrm{ppb}$. For the AOGCM experiments, the control simulation was performed as required by CMIP5/PMIP3 by the LSCE modelling group. It is a $2800 \mathrm{yr}$ simulation which already started from equilibrium conditions.

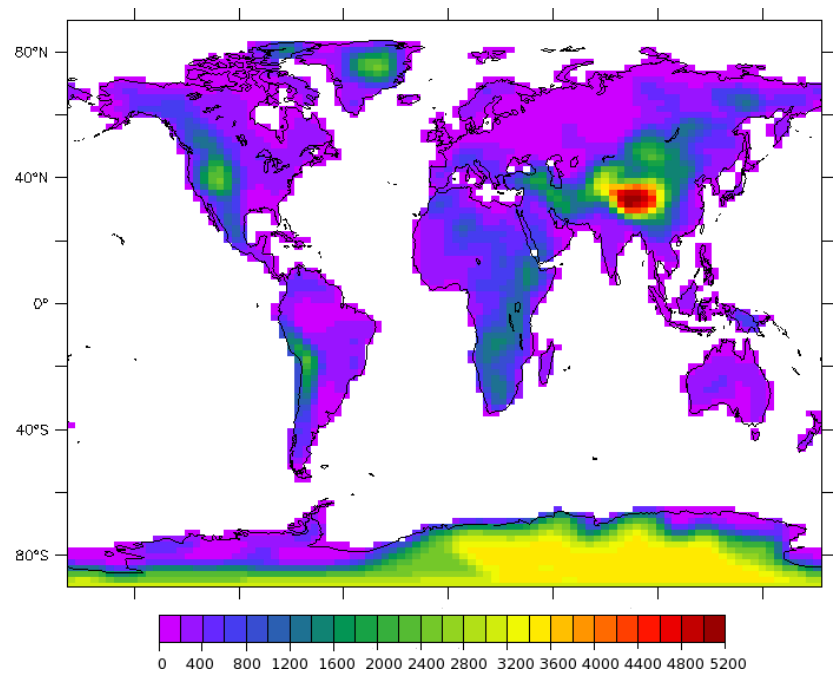

Fig. 2. Absolute implemented mid-Pliocene topography calculated via the anomaly method, expressed in meters.

\subsection{Mid-Pliocene}

The experimental design and boundary conditions follow the protocol of "alternate" simulations described in Haywood et al. $(2010,2011)$ for AGCM and AOGCM simulations. Boundary conditions are built on a modern coastline, because of the challenge of changing the land-sea mask in the ocean model. Since a modern coastline makes the simulation a little unrealistic to be able to compare with data (especially on coastal areas), we decided to perform an AGCM simulation with "preferred" boundary conditions, named Plio1_pref. The difference between results from "alternate" and "preferred" AGCM simulations will be discussed in Sect. 4.4. 


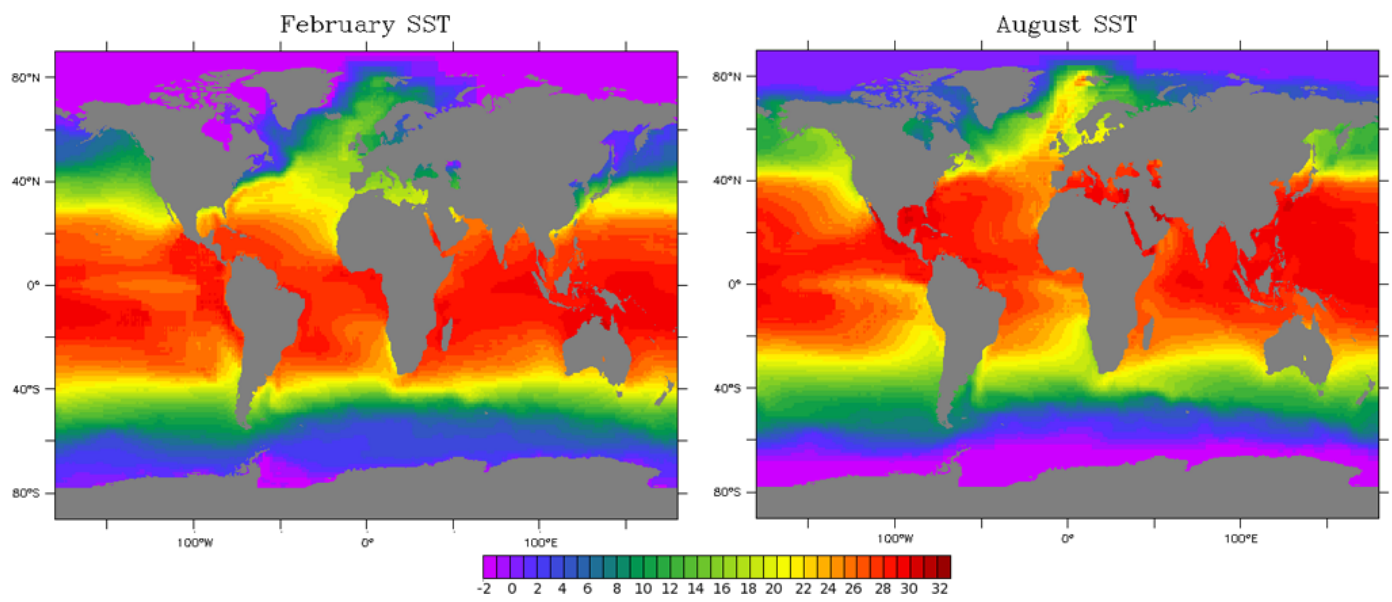

Fig. 3. Mid Pliocene sea surface temperatures imposed for February (left) and August (right), expressed in degrees Celsius.

The AGCM outputs presented below are the ones with alternate boundary conditions, named Plio1_alt.

\subsubsection{Boundary conditions}

For experiment 1 (i.e. for AGCM simulation, as defined in Haywood et al., 2010), two simulations were performed: the first with modern land-sea mask, called Plio1_alt, and the second with Pliocene land-sea mask, Plio1_pref, corresponding to a $25 \mathrm{~m}$ sea-level rise (Fig. 1). The boundary conditions implemented were these given in Haywood et al. (2010), "alternate" set of boundary conditions for Plio1_alt, and "preferred" set for Plio1_pref. Both experiments use the anomaly method for implementation of topography and SSTs, as stated in Haywood et al. (2010, 2011). For topography, the difference between the mid-Pliocene topographic reconstruction (Sohl et al., 2009) and the modern topography provided by the PRISM group (Edwards et al., 1992) was added to the IPSL model topography (Fig. 2). When the resulting topography was lower than zero, absolute mid-Pliocene topography was implemented. The same method was used for SSTs, the difference between the mid-Pliocene SST reconstruction (Dowsett, 2007b; Robinson et al., 2008; Dowsett and Robinson, 2009; Dowsett et al., 2009) and the modern SSTs provided by the PRISM group (Reynolds and Smith, 1995) was added to the IPSL model SSTs (Fig. 3). For the modern scenarios, in AGCM and in AOGCM, modern icesheets are imposed. For the Pliocene scenarios, AGCM and AOGCM, PRISM3 ice-sheets are imposed (Hill et al., 2007; Salzmann et al., 2008; Hill, 2009). For the Pliocene scenarios, regions where ice-sheets are removed are replaced by the corresponding plant functional types from the PRISM3 vegetation reconstruction (Salzmann et al., 2008). For the change of vegetation, the BIOME4 dataset provided by the PRISM3 project (Salzmann et al., 2008) was converted into 28 combinations of 11 plant functional types (PFTs) (Table 1 and Fig. 4) to be used as boundary conditions in the IPSL model.
Ocean gateways were not changed compared to preindustrial conditions (Fig. 1). For river routing and soils, no modification was done. For experiment 2 (i.e. with the AOGCM), the outputs of the "alternate" AGCM simulation are used as a forcing for atmosphere, land surface and carbon cycle components. The ocean starts from the CMIP5/PMIP3 control experiment outputs. For each mid-Pliocene simulation, solar constant, greenhouse gases, aerosols and orbital parameters are the same than in the control run except for $\mathrm{CO}_{2}$ that was prescribed to $405 \mathrm{ppm}$ as required by Haywood et al. (2010, 2011).

\subsubsection{Spin-up and climatological means}

For AGCM experiments (Control, Plio1_alt and Plio1_pref) the spin up was set to $20 \mathrm{yr}$ and presented results are $30 \mathrm{yr}-$ climatological-means, as required by Haywood et al. (2010). For AOGCM experiment, the spin-up was set to $600 \mathrm{yr}$ and the integration length is set to $50 \mathrm{yr}$, the simulation having achieved $650 \mathrm{yr}$ up to now (Fig. 6).

\section{Results}

\subsection{Surface temperature}

Mean annual global values for the main variables can be found in Table 2. With the AGCM, mean annual global warming is $1.94{ }^{\circ} \mathrm{C}$ compared to the control simulation. The mid-Pliocene mean annual temperature is $17^{\circ} \mathrm{C}$, which is similar to the value obtained with MIROC AGCM $\left(16.68^{\circ} \mathrm{C}\right.$, Chan et al., 2011). Warming is larger at high latitudes with an anomaly of $+10^{\circ} \mathrm{C}$ at $80^{\circ} \mathrm{N}$, and $+7.5^{\circ} \mathrm{C}$ at $70^{\circ} \mathrm{S}$ (Figs. 7 and 8). With the coupled AOGCM, a similar warming of $+2.07{ }^{\circ} \mathrm{C}$ is found, although warming at high latitudes is less intense, particularly for the Northern part, where the warming is maximum at $75^{\circ} \mathrm{N}$, and only reaches $+6.57^{\circ} \mathrm{C}$ (Figs. 7 and 9). In the AGCM simulation results, patterns 
Table 1. Conversion of biomes from PRISM3 to ORCHIDEE's Plant Functional Types (Krinner et al., 2012). For the presence of one biome on a grid cell, is attributed a fractional value of one or several PFTs. The sum of the 11 PFT fractions (Fr) on each grid cell must be equal to 1 . PFT1 = barren soil/desert. PFT2 = TrBE : Tropical Broadleaf Evergreen trees. PFT3= TrBR: Tropical Broadleaf Raingreen trees. PFT4 = TeNE: Temperate Needleleaf Evergreen trees. PFT5 = TeBE: Temperate Broadleaf Evergreen trees. PFT6 = TeBS: Temperate Broadleaf Summergreen trees. PFT7 = BoNE: Boreal Needleleaf Evergreen trees. PFT8=BoBS: Boreal Broadleaf Summergreen trees. PFT9 = BoNS: Boreal Needleleaf Summergreen trees. PFT10 = NC3: Natural C3 grass. PFT11 = NC4: Natural C4 grass.

\begin{tabular}{|c|c|c|c|c|c|}
\hline BIOME & $\mathrm{Fr}$ & PFT & BIOME & $\mathrm{Fr}$ & PFT \\
\hline $\begin{array}{l}1 \text { Tropical evergreen } \\
\text { forest }\end{array}$ & 1 & $2 \mathrm{TrBE}$ & $\begin{array}{l}2 \text { Tropical semi_deciduous } \\
\text { forest }\end{array}$ & $\begin{array}{l}0.5 \\
0.5\end{array}$ & $\begin{array}{l}2 \operatorname{TrBE} \\
3 \mathrm{TrBR}\end{array}$ \\
\hline $\begin{array}{l}3 \text { Tropical deciduous } \\
\text { forest/woodland }\end{array}$ & $\begin{array}{l}0.7 \\
0.3\end{array}$ & $\begin{array}{l}3 \mathrm{TrBR} \\
11 \mathrm{NC} 4\end{array}$ & $\begin{array}{l}4 \text { Temperate deciduous } \\
\text { forest }\end{array}$ & $\begin{array}{l}0.1 \\
0.1 \\
0.8\end{array}$ & $\begin{array}{l}4 \text { TeNE } \\
5 \text { TeBE } \\
6 \text { TeBS }\end{array}$ \\
\hline $\begin{array}{l}5 \text { Temperate conifer } \\
\text { forest }\end{array}$ & $\begin{array}{l}0.8 \\
0.1 \\
0.1\end{array}$ & $\begin{array}{l}4 \text { TeNE } \\
5 \text { TeBE } \\
6 \text { TeBS }\end{array}$ & $\begin{array}{l}6 \text { Warm-temperate } \\
\text { mixed forest }\end{array}$ & $\begin{array}{l}0.1 \\
0.4 \\
0.5\end{array}$ & $\begin{array}{l}4 \text { TeNE } \\
5 \text { TeBE } \\
6 \text { TeBS }\end{array}$ \\
\hline 7 Cool mixed forest & $\begin{array}{l}0.4 \\
0.4 \\
0.1 \\
0.1\end{array}$ & $\begin{array}{c}4 \text { TeNE } \\
6 \text { TeBS } \\
7 \text { BoNE } \\
8 \text { BoBS }\end{array}$ & $8 \mathrm{Cool}$ conifer forest & $\begin{array}{l}0.8 \\
0.2\end{array}$ & $\begin{array}{l}4 \mathrm{TeNE} \\
6 \mathrm{TeBS}\end{array}$ \\
\hline 9 Cold mixed forest & $\begin{array}{l}0.4 \\
0.5 \\
0.1\end{array}$ & $\begin{array}{l}7 \text { BoNE } \\
8 \text { BoBS } \\
9 \text { BoNS }\end{array}$ & $\begin{array}{l}10 \text { Evergreen taiga/ } \\
\text { montane forest }\end{array}$ & $\begin{array}{l}0.9 \\
0.1\end{array}$ & $\begin{array}{l}7 \text { BoNE } \\
8 \text { BoBS }\end{array}$ \\
\hline $\begin{array}{l}11 \text { Deciduous taiga/ } \\
\text { montane forest }\end{array}$ & $\begin{array}{l}0.3 \\
0.7\end{array}$ & $\begin{array}{l}8 \text { BoBS } \\
9 \text { BoNS }\end{array}$ & 12 Tropical savanna & $\begin{array}{l}0.3 \\
0.2 \\
0.5\end{array}$ & $\begin{array}{l}3 \mathrm{TrBR} \\
10 \mathrm{NC} 3 \\
11 \mathrm{NC} 4\end{array}$ \\
\hline $\begin{array}{l}13 \text { Tropical xerophytic } \\
\text { shrubland }\end{array}$ & $\begin{array}{l}0.2 \\
0.3 \\
0.5\end{array}$ & $\begin{array}{c}1 \text { Barren } \\
3 \text { TrBR } \\
11 \text { NC4 }\end{array}$ & $\begin{array}{l}14 \text { Temperate } \\
\text { xerophytic shrubland }\end{array}$ & $\begin{array}{l}0.2 \\
0.2 \\
0.6\end{array}$ & $\begin{array}{r}1 \text { Barren } \\
5 \mathrm{TeBE} \\
10 \mathrm{NC} 3\end{array}$ \\
\hline $\begin{array}{l}15 \text { Temperate sclerophyll } \\
\text { woodland }\end{array}$ & $\begin{array}{l}0.3 \\
0.3 \\
0.4\end{array}$ & $\begin{array}{l}4 \mathrm{TeNE} \\
5 \mathrm{TeBE} \\
10 \mathrm{NC} 3\end{array}$ & $\begin{array}{l}16 \text { Temperate } \\
\text { broadleaved } \\
\text { savanna }\end{array}$ & $\begin{array}{l}0.2 \\
0.2 \\
0.6\end{array}$ & $\begin{array}{c}5 \mathrm{TeBE} \\
6 \mathrm{TeBS} \\
10 \mathrm{NC} 3\end{array}$ \\
\hline $\begin{array}{l}17 \text { Open conifer } \\
\text { woodland }\end{array}$ & $\begin{array}{l}0.4 \\
0.6\end{array}$ & $\begin{array}{l}4 \mathrm{TeNE} \\
10 \mathrm{NC} 3\end{array}$ & 18 Boreal parkland & $\begin{array}{l}0.1 \\
0.2 \\
0.1 \\
0.6\end{array}$ & $\begin{array}{l}7 \text { BoNE } \\
8 \text { BoBS } \\
9 \text { BoNS } \\
10 \text { NC3 }\end{array}$ \\
\hline 19 Tropical grassland & $\begin{array}{c}0.1 \\
0.03 \\
0.87\end{array}$ & $\begin{array}{c}1 \text { Barren } \\
3 \text { TrBR } \\
11 \text { NC4 }\end{array}$ & $\begin{array}{l}20 \text { Temperate } \\
\text { grassland }\end{array}$ & $\begin{array}{l}0.03 \\
0.97\end{array}$ & $\begin{array}{l}5 \mathrm{TeBE} \\
10 \mathrm{NC} 3\end{array}$ \\
\hline 21 Desert & 1 & 1 Barren & 22 Steppe tundra & $\begin{array}{l}0.3 \\
0.7\end{array}$ & $\begin{array}{r}1 \text { Barren } \\
10 \mathrm{NC} 3\end{array}$ \\
\hline 23 Shrub tundra & $\begin{array}{l}0.3 \\
0.7\end{array}$ & $\begin{array}{l}8 \mathrm{BoBS} \\
10 \mathrm{NC} 3\end{array}$ & $\begin{array}{l}24 \text { Dwarf-shrub } \\
\text { tundra }\end{array}$ & $\begin{array}{l}0.2 \\
0.8\end{array}$ & $\begin{array}{l}8 \mathrm{BoBS} \\
10 \mathrm{NC} 3\end{array}$ \\
\hline $\begin{array}{l}25 \text { Prostrate } \\
\text { shrub tundra }\end{array}$ & $\begin{array}{l}0.1 \\
0.9\end{array}$ & $\begin{array}{l}8 \mathrm{BoBS} \\
10 \mathrm{NC} 3\end{array}$ & $\begin{array}{l}26 \text { Cushion-forb lichen } \\
\text { moss tundra }\end{array}$ & $\begin{array}{l}0.1 \\
0.9\end{array}$ & $\begin{array}{r}1 \text { Barren } \\
10 \mathrm{NC} 3\end{array}$ \\
\hline 27 Barren soil & 1 & 1 Barren & 28 Land ice & 1 & 1 Barren \\
\hline
\end{tabular}



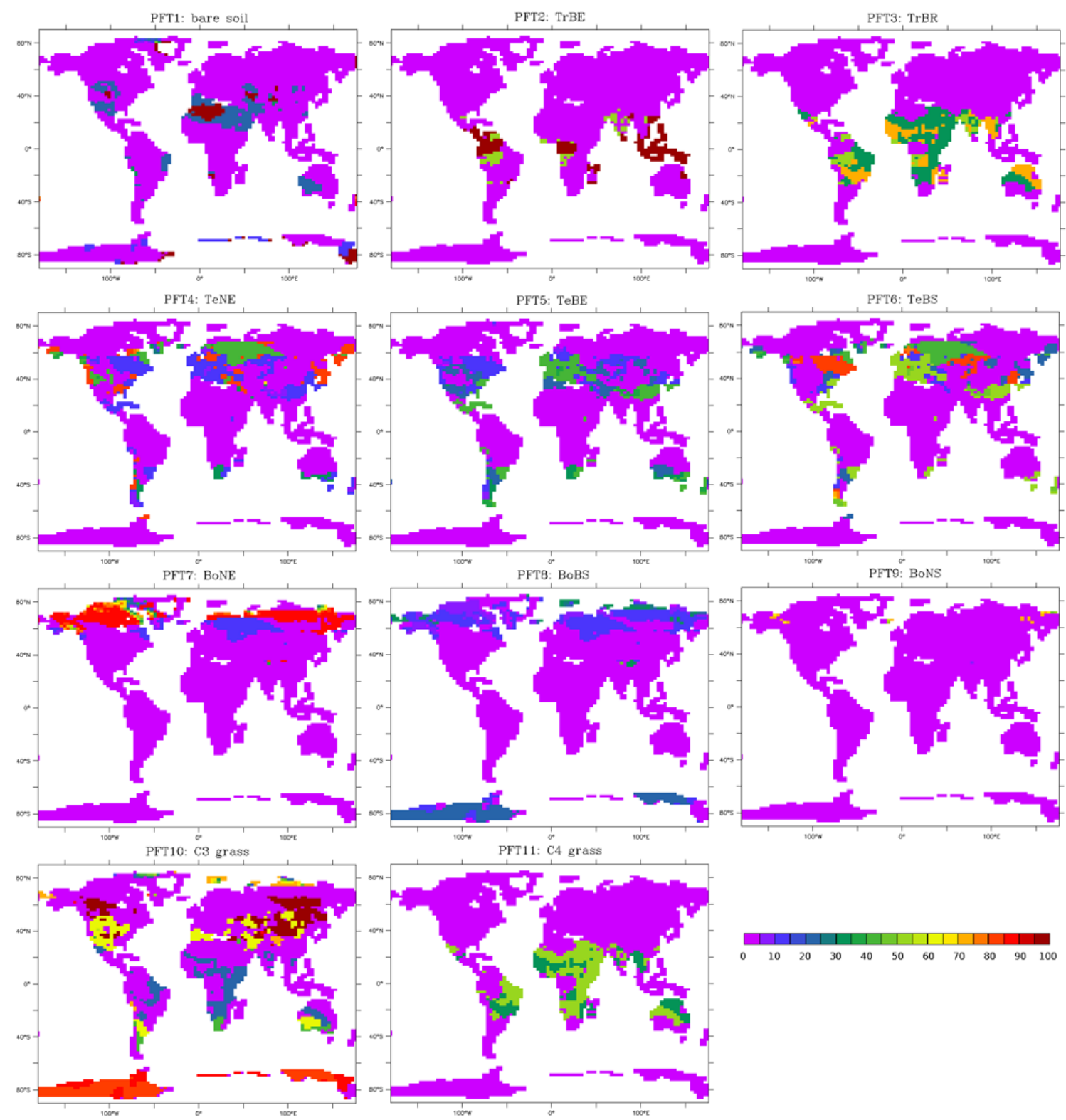

Fig. 4. mPWP imposed percentage of each PFT in the ORCHIDEE model, on the alternate land-sea mask for every grid cell where land fraction is superior to zero.

of several degrees of cooling also appear, particularly in June-July-August for regions of the Northern Hemisphere, namely Central and Eastern Africa, India and the Himalayas; and in December-January-February over Australia (Fig. 8). These cooling patterns do not exist in the AOGCM simulation, which on the opposite, shows a small warming in these regions (Fig. 9). These differences can be explained by the difference between calculated SSTs and imposed SSTs (Fig. 12, right panel). Changes of temperature on mountain regions, that are similar in both simulations, can be explained by the change in topography. Regions which show a cooling coincide with higher elevation during the mid-Pliocene:
Eastern Antarctica, eastern part of the Andes, eastern part of the Rocky Mountains, southern Himalaya. Conversely, increase in temperature is found where topography is lower: coastal Eastern Antarctica, West Antarctica, Western Greenland, Western Andes, Western Rocky mountains and Northern Himalayas. On Greenland and Antarctica, the removal of the ice-sheets creates a great warming which is due to both albedo (Fig. 5) and topography effects. Simulated warming over Greenland and Antarctica is similar in the AGCM and AOGCM, with temperature anomalies reaching +25 to $+30^{\circ} \mathrm{C}$. These values are similar to the AGCM results of Koenig et al. (2012). In the tropics, warming is larger in the 


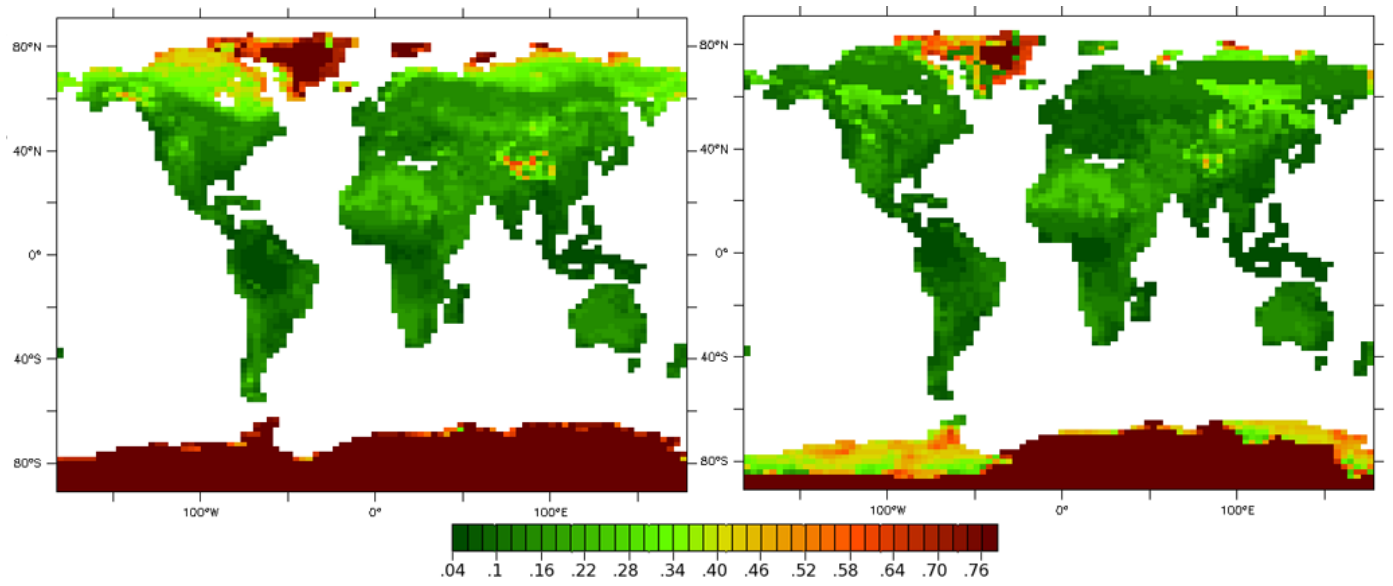

Fig. 5. Land surface albedo for the Control (left) and the mid-Pliocene (right) experiments, on the alternate land-sea mask, for every grid cell where land fraction or land ice fraction is superior to zero.
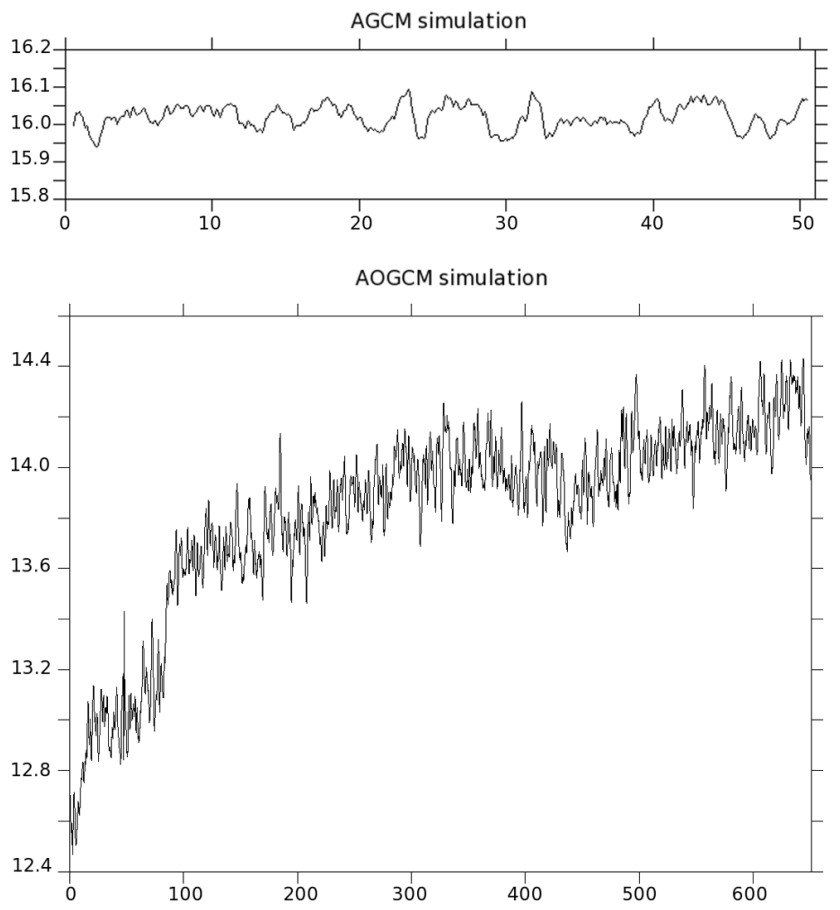

Fig. 6. Evolution of the globally averaged $2 \mathrm{~m}$ temperature for the AGCM and AOGCM, expressed in degrees Celsius.

AOGCM simulation than in the AGCM simulation (Fig. 7, right panel).

\subsection{Precipitation}

Although there is almost no change in the global values of precipitation, (Table $2,+0.05 \mathrm{~mm} \mathrm{day}^{-1}$ for AGCM, and $+0.13 \mathrm{~mm} \mathrm{day}^{-1}$ for AOGCM), precipitation patterns are significantly impacted in the AGCM (Fig. 11, upper panel). Indeed, there are significant changes at low latitudes:

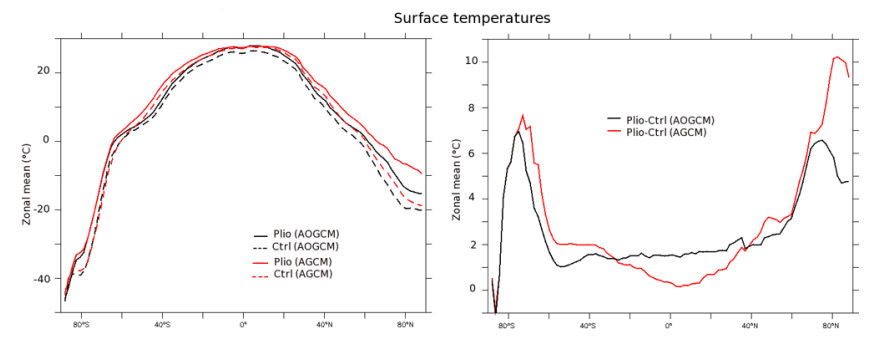

Fig. 7. Zonal mean surface temperature for the mid-Pliocene experiments and the control (left), and zonal mean surface temperature anomaly to the control for both Pliocene experiments (right), expressed in degrees Celsius.

precipitation increases in many regions like Central Africa, Northern and Eastern Australia, and some parts of the Amazon Basin. Meanwhile, precipitation decreases in the tropical Indian and Pacific Oceans. These differences are similar to those observed with the MRI AGCM, explained by a general slowing down of the Walker circulation due to the reduced East-West SST gradient in the tropics (Kamae et al., 2011), which induces a broadening of the ITCZ (Figs. 10, right panel and 11, upper panel). There is also an increase in precipitation over the North Atlantic region, where imposed SSTs show a great warming (Fig. 11, upper panel). Moreover the data provided over Pacific with a Western tropical Pacific unchanged but an Eastern Pacific temperature increase of around $4{ }^{\circ} \mathrm{C}$ induce a weakening of the Walker cell which has been interpreted as a permanent El-Niño (Ravelo et al., 2004). This pattern has been shown to explain large scale precipitation changes (Kamae et al., 2011). All these features are also observed in our simulation, especially concerning the precipitation pattern. This is the response of AGCM to SST changes. Most of PlioMIP AGCMs may depict these features. However, in the AOGCM, precipitation response is different from the AGCM one. There is no significant change 
Table 2. Comparative table of global mean values for the AGCM and AOGCM mid-Pliocene simulations.

\begin{tabular}{|c|c|c|c|c|c|}
\hline Variable & Units & $\begin{array}{l}\text { AGCM } \\
\text { absolute }\end{array}$ & $\begin{array}{r}\text { AGCM } \\
\text { anomaly to Ctrl }\end{array}$ & $\begin{array}{l}\text { AOGCM } \\
\text { absolute }\end{array}$ & $\begin{array}{r}\text { AOGCM } \\
\text { anomaly to Ctrl }\end{array}$ \\
\hline Surface air temperature & ${ }^{\circ} \mathrm{C}$ & 17 & 1.94 & 15.2 & 2.07 \\
\hline Total precipitation & $\mathrm{mm} \mathrm{day}^{-1}$ & 2.89 & 0.05 & 2.79 & 0.13 \\
\hline Rainfall & $\mathrm{mm} \mathrm{day}^{-1}$ & 2.75 & 0.09 & 2.62 & 0.16 \\
\hline Snowfall & $\mathrm{mm} \mathrm{day}^{-1}$ & 0.14 & -0.04 & 0.17 & -0.03 \\
\hline Sea surface temperature & ${ }^{\circ} \mathrm{C}$ & 19.75 & 1.5 & 18.03 & 1.4 \\
\hline Sea surface salinity & psu & - & - & 34.35 & -0.08 \\
\hline TOA net down radiative flux & $\mathrm{W} \mathrm{m}^{-2}$ & 2.43 & 3.66 & 0.69 & 0.49 \\
\hline
\end{tabular}
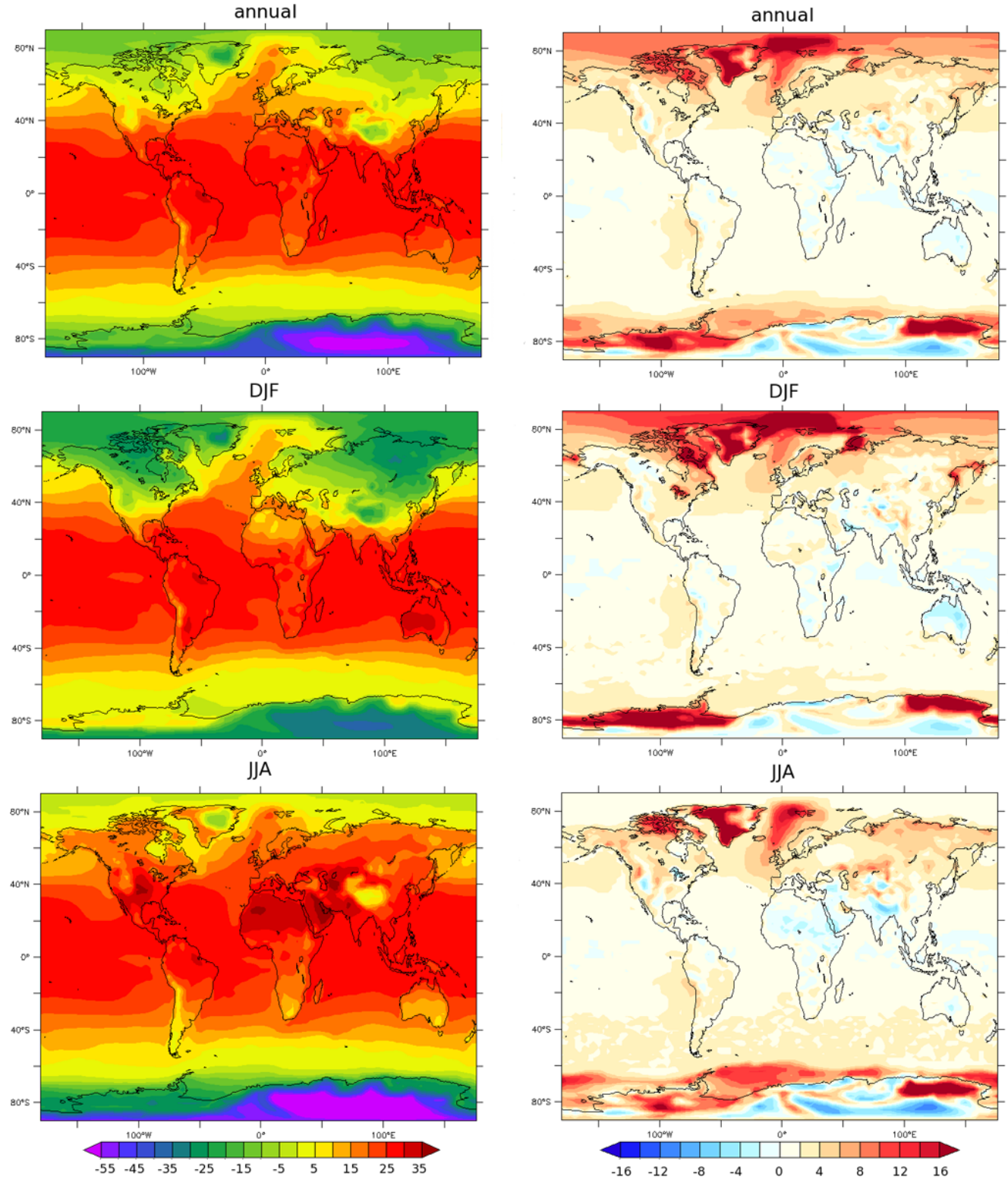

Fig. 8. AGCM mid-Pliocene (Plio1_alt) mean surface temperatures (left) for yearly average, December-January-February, June-July-August, and their anomaly to the control (right), expressed in degrees Celsius. 

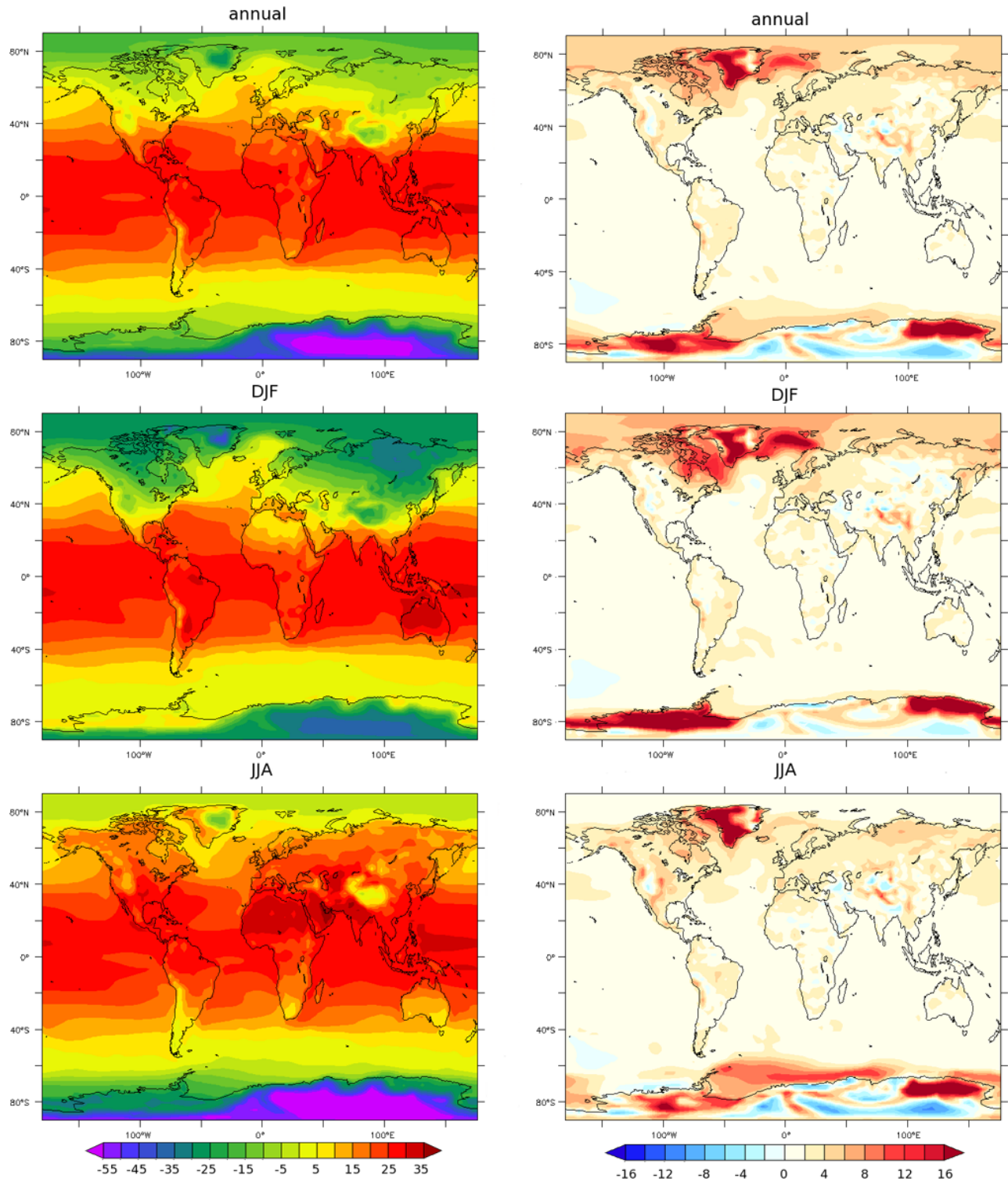

Fig. 9. AOGCM mid-Pliocene mean surface temperatures (left) for yearly average, December-January-February, June-July-August, and their anomaly to the control (right), expressed in degrees Celsius.
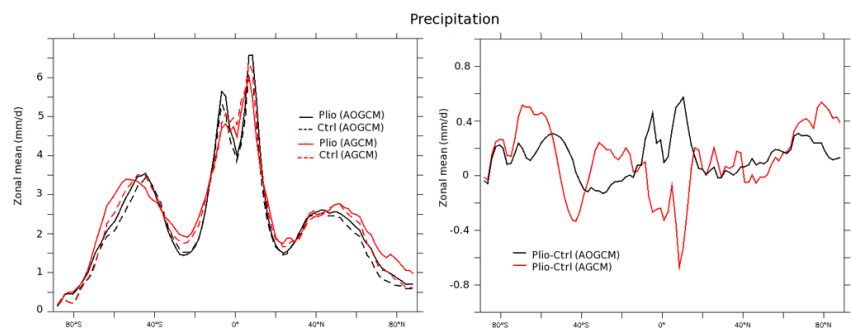

Fig. 10. Zonal annual mean precipitation for the control and the mid-Pliocene experiments (left). Zonal mean precipitation anomaly to the control for both Pliocene experiments (right). in the precipitation pattern, but a precipitation increase inside the ITCZ (Fig. 11, lower right panel). These differences between AGCM and AOGCM are explained by the differences between calculated SSTs in the AOGCM and imposed SSTs in the AGCM (Fig. 12, right panel) and are further investigated in the Discussion section.

\subsection{Sea surface temperature}

One of the challenges of mPWP coupled model simulations is to investigate if the North Atlantic high warming pattern inferred from SST reconstructions can be reproduced. Our AOGCM simulation reproduces some warming in the Norwegian and Barents Seas, and in some regions of the North 

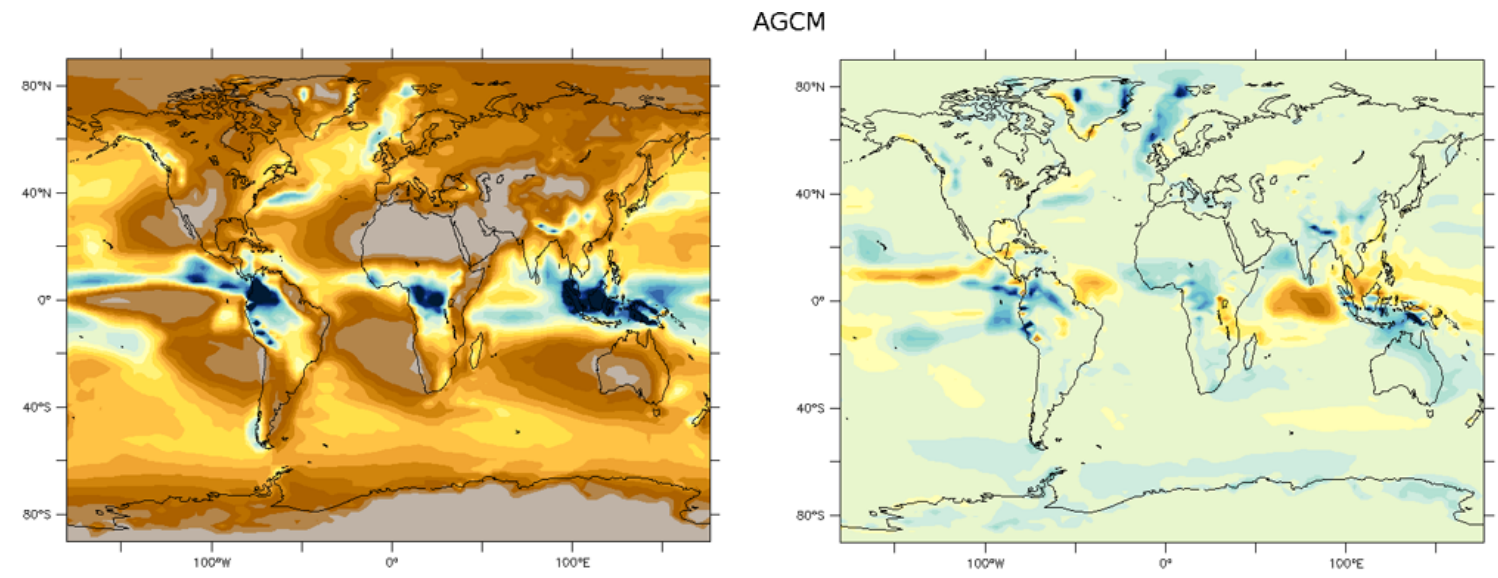

AOGCM
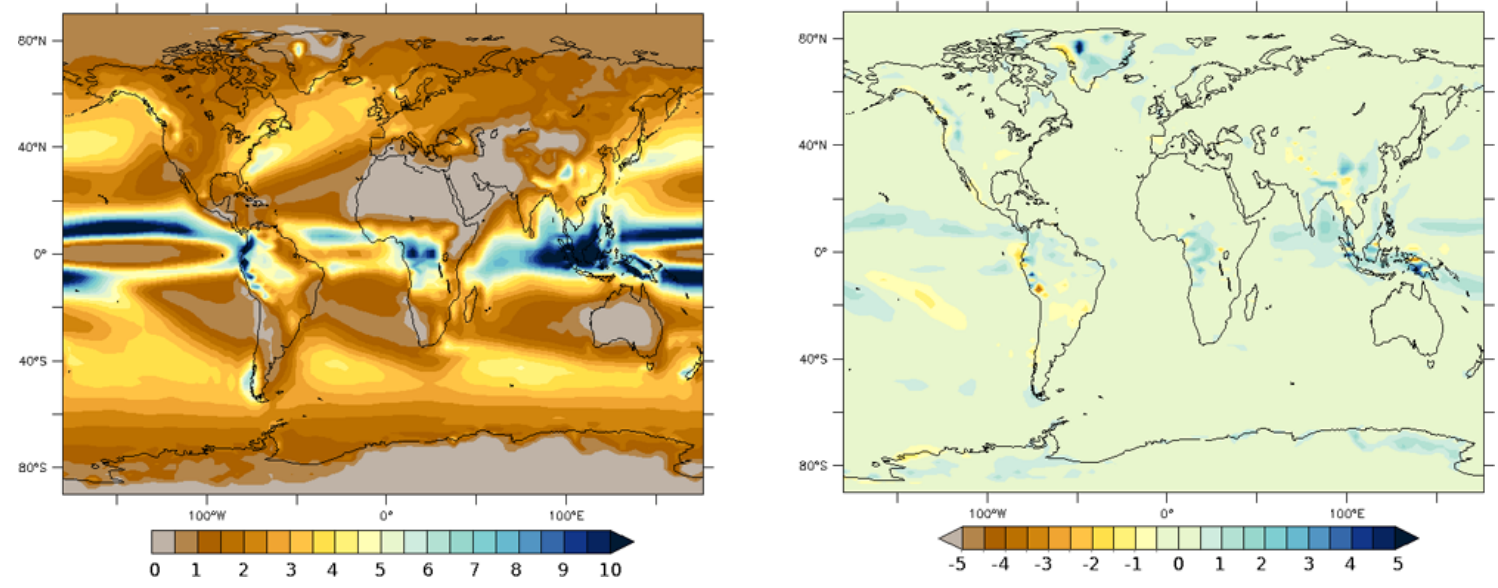

Fig. 11. Mid-Pliocene mean annual precipitation (left) for AGCM (top) and AOGCM (bottom), and their anomaly to the control (right), expressed in mm day $^{-1}$.

Atlantic Ocean (Fig. 12, left panel) but is unsuccessful in reproducing the global warming pattern in the Norwegian and Barents Seas, Artic Ocean and North Atlantic (Fig. 12, right panel) shown in the PRISM3 SST dataset (Dowsett, 2007b; Robinson et al., 2008; Dowsett and Robinson, 2009; Dowsett et al., 2009). Globally, SSTs are warmer than the control, except in the Southern Pacific, where SSTs are slightly cooler. Moreover, the tropical SST increase is larger in the AOGCM than the imposed SST anomaly in the AGCM (Fig. 12, right panel).The other main interest of coupled AOGCM simulations is to investigate whether the East-West SST gradient is reduced in the tropical Pacific. In our simulation, the tropical oceans, including the Pacific, warm uniformly (Fig. 12, left panel), there is no differential warming in the Eastern Pacific which could induce a reduction of the East-West gradient. The reconstructed pattern of warming in the Eastern tropical Pacific could be related with variability in the Pacific, which may not be properly captured by AOGCM simulations (Ravelo et al., 2004).

\subsection{Sensitivity test to the change of land-sea mask in the AGCM}

The change in sea-level is likely to be changing climate in coastal areas. Notably, we are interested in its impact on Antarctica, because it is the region most impacted by the sea-level rise (Fig. 1). The surface temperature and total precipitation differences between the AGCM simulation with "preferred" boundary conditions and the one with "alternate" boundary conditions can be seen in Fig. 13. Significant changes of surface temperature appear where grid cells were turned from land to sea, or conversely. The largest warming signal is observed on the Hudson Bay and on the coast of Eastern Antarctic. However, this temperature change is not correlated with a precipitation change. It seems that, at least as simulated with LMDZ5A, the $25 \mathrm{~m}$ sea-level rise could have an impact on the ice-sheet melting, because some areas are subject to an increase in temperature. However, there is no precipitation change over the polar regions, a small sea-level rise might not affect the growth of the ice-sheet. Meanwhile, precipitation patterns are impacted in the tropics, 


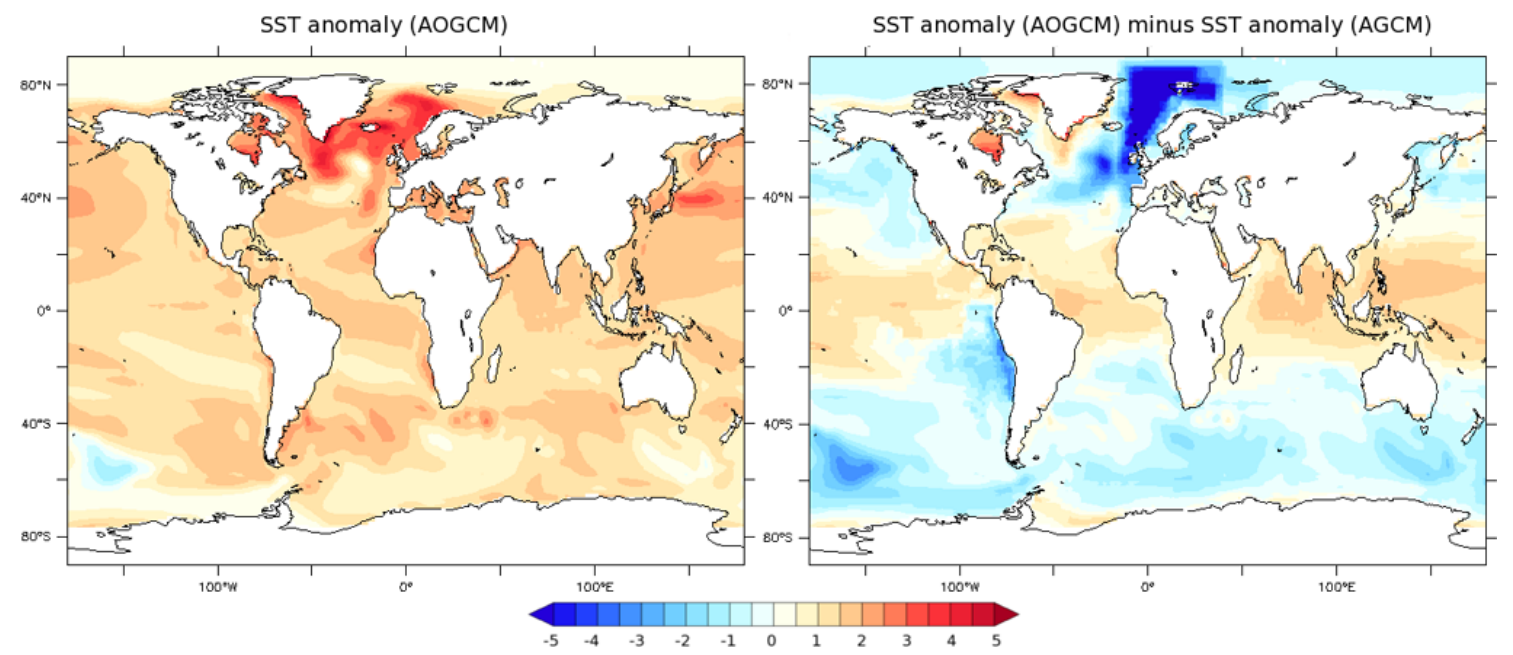

Fig. 12. SST anomaly between the mid-Pliocene and the control AOGCM simulations (left). Difference between AOGCM simulated SST anomaly and AGCM imposed SST anomaly (right).

namely, it increases over the Caribbeans and in Indonesia, where precipitation increases in the Southern part while it decreases in the Northern part, probably because of the landsea distribution change (Fig. 1). This issue could be further investigated using a coupled AOGCM which would calculate the SST and sea-ice change correlated with a $25 \mathrm{~m}$ sea-level rise.

\section{Discussion}

It is important to note that the simulated warming is close to $+2{ }^{\circ} \mathrm{C}$ for both AGCM and AOGCM simulations, which is a reasonable value for annually averaged surface temperature anomaly compared to other AGCM simulations (Koenig et al., 2012; Yan et al., 2012), and is slightly cooler compared to other AOGCM simulations which reach around $+3^{\circ} \mathrm{C}$ of warming compared to their control (Chan et al., 2011; Zhang et al., 2012). The warming pattern is also similar to other PlioMIP simulations: warming is mostly concentrated at high latitudes with large areas experiencing a very high warming, namely Greenland, some parts of Antarctica, North Atlantic Ocean and Southern Ocean during austral winter (Figs. 8 and 9). Nevertheless there are major differences in AGCM and AOGCM simulations. First, even if the largest increase in global temperature is obtained using the AOGCM, the absolute warmest mid-Pliocene simulation is the AGCM one (cf. Table 2). This is due to the fact that the AOGCM control simulation is cooler than the AGCM control one. The zonal distribution of the warming in the mid-Pliocene simulations compared to the control (Fig. 7, right panel), differs in particular in the Northern high latitudes between AGCM and AOGCM. Similarly to other AGCM simulations (Koenig et al., 2012; Yan et al., 2012), prescribed SSTs imposed this pattern in the Northern high latitudes. In the tropics, large monsoon changes are produced by the imposed SSTs (Fig. 11, upper right panel). Previous studies using PRISM2 boundary conditions (Dowsett et al., 1999; Dowsett, 2007a) and AGCM (Haywood et al., 2009) have shown that the large changes in high latitude SSTs versus mostly unchanged equatorial SSTs produce a large weakening of the Hadley cell. This feature is indeed amplified by albedo feedback due to the reduction of sea-ice and land-ice cover (Koenig et al., 2012). The same mechanism is observed but for cold conditions when an AGCM simulates the Last Glacial Maximum climate: due to the increase of the equator to pole gradient, the Hadley cell increases (Ramstein et al., 1998; Jost et al., 2005). More recently, using the new dataset PRISM3 (Dowsett, 2007b; Robinson et al., 2008; Dowsett and Robinson, 2009; Dowsett et al., 2009), new AGCM simulations depict that the large scale pattern of mid-Pliocene SSTs induces a major re-organisation of atmospheric circulation, the Hadley cell response is shown to weaken with its ascending branches extending polewards (Kamae et al., 2011; Yan et al., 2012). The AOGCM simulation is therefore interesting because the ocean is free to respond to the mid-Pliocene forcing. The major difference is the reduced heat export from equator to pole, leading to a warmer tropical ocean and a seriously reduced warming for both hemispheres high latitudes but mainly for North Atlantic (Figs. 7 and 12, right panel). These features are not specific to the IPSL model and demonstrate that there is some missing feedback if simulations have to reproduce the data in these regions. Most of AOGCM simulations do not show a consistent North Atlantic heat transport compared to data. From that point of view thanks to the PlioMIP comparison, a large number of model results are available to investigate whether some feedback could be identified to reconcile simulations and data over this region. On the other hand we have to keep a critical eye on alkenone 

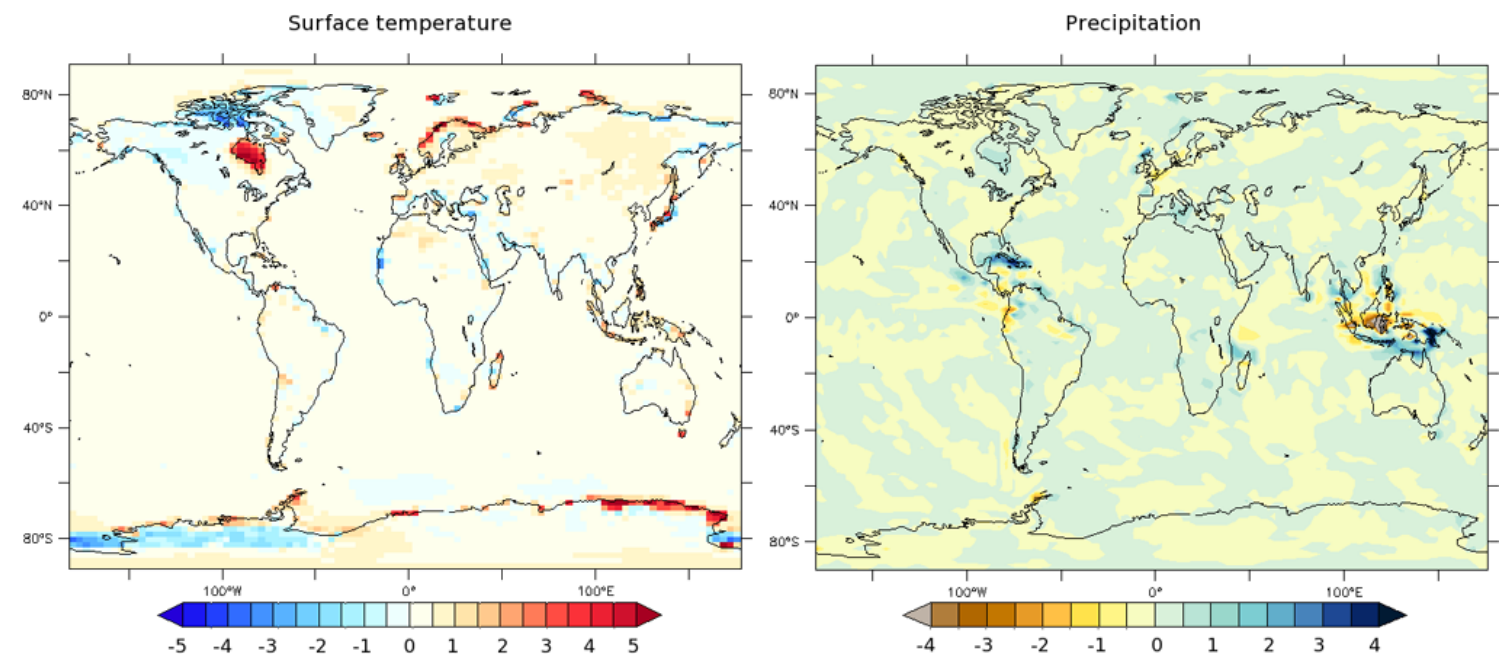

Fig. 13. Surface temperature difference between the "preferred" AGCM simulation and the "alternate" AGCM simulation, i.e. Plio1_pref minus Plio1_alt, expressed in degrees Celsius (left) and total precipitation difference (Plio1_pref minus Plio1_alt) expressed in mm day ${ }^{-1}$ (right).

data, which could possibly represent summer temperatures (Leduc et al., 2010).

\section{Summary and conclusions}

The mid-Pliocene Warm Period is the last sustained period of time (3.3 to $3 \mathrm{Ma}$ ) when temperatures reached +2 to $+3{ }^{\circ} \mathrm{C}$ of warming compared to today. Sea surface temperature reconstructions show that warming is larger at high latitudes, and so do model results. Since the mid-Pliocene Warm Period can be considered as an interesting period to compare with future global warming in terms of $\mathrm{CO}_{2}$ concentration and magnitude of the warming, this period is of high interest for understanding feedbacks and mechanisms that sustained such a warm climate. The PlioMIP will help understand the strengths and weaknesses of each model when simulating a warmer than today climate. Areas where there is a model/data mismatch may be good targets to understand regional features. Multi-model comparison can also help us to pinpoint the processes involved in such a warming. In this study, we described the implementation of the PRISM boundary conditions in our model, which closely followed the guidelines of PlioMIP (Haywood et al., 2010, 2011). The main difference with the guidelines is that we started the ocean model from pre-industrial control conditions, and did not include any mid-Pliocene ocean temperatures reconstructions to force the ocean model. We implemented the "alternate" set of boundary conditions for simulations with AGCM and AOGCM, and included the results of one additional experiment with the AGCM, this time with "preferred" boundary conditions. This sensitivity test showed to have a significant impact on coastal surface temperature, but a weak impact on precipitation especially over the polar regions. For
mid-Pliocene AGCM simulation, we find a global warming of $1.94{ }^{\circ} \mathrm{C}$ compared to the control, which is in agreement with previous simulations with AGCMs (Koenig et al., 2012; Yan et al., 2012), and a broadening of the ITCZ due to reduced SST gradients, also in good agreement with other AGCM results (Kamae et al., 2011; Yan et al., 2012). For the AOGCM simulation, the global simulated warming is $2.07^{\circ} \mathrm{C}$, a slightly cooler value than with other AOGCMs (Chan et al., 2011; Zhang et al., 2012). We find that precipitation patterns are different in AGCM and AOGCM, due to the inability of the AOGCM to reproduce SST reconstructed patterns. To conclude, it is now important to focus on the multi-model analysis, to determine which processes are well reproduced and what are the governing mechanisms under a warmer climate.

Acknowledgements. We thank Pierre Sepulchre and Masa Kageyama for their help with the model and Arnaud Caubel for providing Pre-industrial control simulations with the coupled model. Many thanks to Jean-Yves Peterschmitt for technical assistance. We thank Harry Dowsett and an anonymous reviewer for their useful comments which improved the quality of the manuscript.

Edited by: J. C. Hargreaves

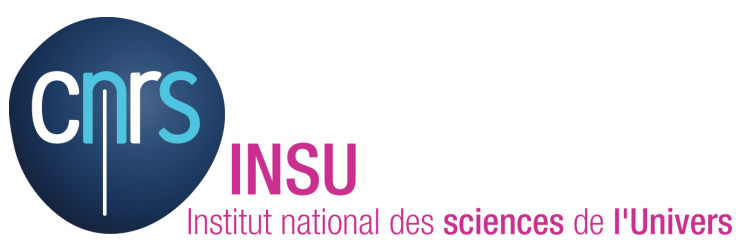

The publication of this article is financed by CNRS-INSU. 


\section{References}

Arakawa, A. and Lamb, V. R.: A potential enstrophy and energy conserving scheme for the shallow water equations, Mon. Weather Rev., 109, 18-36, 1981.

Chan, W.-L., Abe-Ouchi, A., and Ohgaito, R.: Simulating the midPliocene climate with the MIROC general circulation model: experimental design and initial results, Geosci. Model Dev., 4, 1035-1049, doi:10.5194/gmd-4-1035-2011, 2011.

Chandler, M. A., Rind, D., and Thompson, R. S.: Joint investigations of the middle Pliocene climate II: GISS GCM Northern Hemisphere results, Global Planet. Change, 9, 197-219, 1994.

Cravatte, S., Madec, G., Izumo, T., Menkes, C., and Bozec A.: Progress in the 3-D circulation of the eastern equatorial $\mathrm{Pa}$ cific in a climate ocean model, Ocean Model., 17, 28-48, doi:10.1016/j.ocemod.2006.11.003, 2007.

Crowley, T. J.: Modeling Pliocene warmth, Quat. Sci. Rev., 10, 272282, 1991.

Crowley, T. J.: Pliocene climates: The nature of the problem, Mar. Micropaleontol., 27, 3-12, 1996.

de Rosnay, P. and Polcher, J.: Modelling root water uptake in a complex land surface scheme coupled to a GCM, Hydrol. Earth Syst. Sci., 2, 239-255, doi:10.5194/hess-2-239-1998, 1998.

Dowsett, H. J.: The PRISM Palaeoclimate Reconstruction and Pliocene Sea-Surface Temperature, in: Deep Time Perspectives on Climate Change: Marrying the Signal from Computer Models and Biological Proxies, edited by: Williams, M., Haywood, A. M., Gregory, F. J., and Schmidt, D. H., Micropalaeontol. Soc., Spec. Pub. Geol. Soc., London, 517-538, 2007a.

Dowsett, H. J.: Faunal re-evaluation of Mid-Pliocene conditions in the western equatorial Pacific, Micropaleontology, 53, 447-456, 2007b.

Dowsett, H. J. and Robinson, M. M.: Mid-Pliocene equatorial Pacific sea surface temperature reconstruction: a multi-proxy perspective: Phil. Trans. R. Soc. A, 367, 109-126, 2009.

Dowsett, H. J., Barron, J. A., Poore, R. Z., Thompson, R. S., Cronin, T. M., Ishman, S. E., and Willard, D. A.: Pliocene Paleoenvironmental Reconstruction, US Geological Survey Open File Report, 99-535, 1999.

Dowsett, H. J., Robinson, M. M., and Foley, K. M.: Pliocene threedimensional global ocean temperature reconstruction, Clim. Past, 5, 769-783, doi:10.5194/cp-5-769-2009, 2009.

Ducoudré, N. I., Laval, K., and Perrier, A.: SECHIBA, a new set of parameterizations of the hydrologic exchanges at the landatmosphere interface within the LMD atmospheric general circulation model, J. Climate, 6, 248-273, 1993.

Dufresne J.-L., Quaas, J., Boucher, O., Denvil, S., and Fairhead, L.: Contrasts in the effects on climate of anthropogenic sulfate aerosols between the 20th and the 21st century, Geophys. Res. Lett., 32, L21703, doi:10.1029/2005GL023619, 2005.

Dufresne, J-L, Foujols, M-A., Denvil, S., Caubel, A., Marti, O. Aumont, O., Balkanski, Y., Bekki, S., Bellenger, H., Benshila, R., Bony, S., Bopp, L., Braconnot, P., Brockmann, P., Cadule, P., Cheruy, F., Codron, F., Cozic, A., Cugnet, D., de Noblet, N., Duvel, J.-P., Ethé, C., Fairhead, L., Fichefet, T., Flavoni, S., Friedlingstein, P., Grandpeix, J.-Y., Guez, L., Guilyardi, E., Hauglustaine, D., Hourdin, F., Idelkadi, A., Ghattas, J., Joussaume, S., Kageyama, M., Krinner, G., Labetoulle, S., Lahellec, A., Lefebvre, M.-P., Lefevre, F., Levy, C., Li, Z.-X., Lloyd, J., Lott, F., Madec, G., Mancip, M., Marchand, M., Masson, S.,
Meurdesoif, Y., Mignot, J., Musat, I., Parouty, S., Polcher, J., Rio, C., Schulz, M, Swingedouw, D., Szopa, S., Talandier, C., Terray, P., and Viovy, N.: Climate change projections using the IPSL-CM5 Earth System Model: from CMIP3 to CMIP5, Clim. Dynam., submitted, 2012.

Edwards, M.: Global Gridded Elevation and Bathymetry, in: Global Ecosystems Database, Version 1.0 (on CD-ROM), Documentation Manual, Disc-A: National Geophysical Data Center, Key to Geophysical Records Documentation No. 26 (Incorporated in: Global Change Database, Volume 1), edited by: Kineman, J. J. and Ohrenschall, M. A., Boulder, CO, National Oceanic and Atmospheric Administration, A14-1 to A14-4, 1992.

Fichefet, T. and Morales-Maqueda, M. A.: Sensitivity of a global sea ice model to the treatment of ice thermodynamics and dynamics, J. Geophys. Res., 102, 12609-12646, doi:10.1029/97JC00480, 1997.

Fichefet, T. and Morales-Maqueda, M. A.: Modelling the influence of snow accumulation and snow-ice formation on the seasonal cycle of the Antarctic sea-ice cover, Clim. Dynam., 15, 251-268, doi:10.1007/s003820050280, 1999.

Haywood, A. M., Valdes, P. J., and Sellwood, B. W.: Global scale palaeoclimate reconstruction of the middle Pliocene climate using the UKMO GCM: initial results, Global Planet. Change, 25, 239-256, 2000.

Haywood, A. M., Chandler, M. A., Valdes, P. J., and Salzmann, U.: Comparison of mid-Pliocene climate predictions produced by the HadAM3 and GCMAM3 General Circulation Models, Global Planet. Change, 66, 208-224, 2009.

Haywood, A. M., Dowsett, H. J., Otto-Bliesner, B., Chandler, M. A., Dolan, A. M., Hill, D. J., Lunt, D. J., Robinson, M. M., Rosenbloom, N., Salzmann, U., and Sohl, L. E.: Pliocene Model Intercomparison Project (PlioMIP): experimental design and boundary conditions (Experiment 1), Geosci. Model Dev., 3, 227-242, doi:10.5194/gmd-3-227-2010, 2010.

Haywood, A. M., Dowsett, H. J., Robinson, M. M., Stoll, D. K., Dolan, A. M., Lunt, D. J., Otto-Bliesner, B., and Chandler, M. A.: Pliocene Model Intercomparison Project (PlioMIP): experimental design and boundary conditions (Experiment 2), Geosci. Model Dev., 4, 571-577, doi:10.5194/gmd-4-571-2011, 2011.

Hill, D. J.: Modelling Earth's Cryosphere during Pliocene Warm Peak, Ph.D. thesis, University of Bristol, UK, 368 pp., 2009.

Hill, D. J., Haywood, A. M., Hindmarsh, R. C. A., and Valdes, P. J.: Characterising ice sheets during the mid-Pliocene: evidence from data and models, In: Deep Time Perspectives on Climate Change: Marrying the Signal from Computer Models and Biological Proxies, edited by: Williams, M., Haywood, A. M., Gregory, F. J. and Schmidt, D. H., Micropalaeontol. Soc., Spec. Pub. Geol. Soc., London, 517-538, 2007.

Hourdin, F., Musat, I., Bony, S., Braconnot, P., Codron, F., Dufresne, J.-F., Fairhead, L., Filiberti, M.-A., Friedlingstein, P., Grandpeix, J.-Y., Levan, P., Li, Z.-X., and Lott, F.: The LMDZ4 general circulation model: climate performance and sensitivity to parametrized physics with emphasis on tropical convection, Clim. Dynam., 27, 787-813, 2006.

Hourdin F., Foujols, M.-A., Codron, F., Guemas, V., Dufresne, J.L., Bony, S., Denvil, S., Guez, L., Lott, F., Ghattas, J., Braconnot, P., Marti, O., Meurdesoif, Y., and Bopp, L.: Climate and sensitivity of the IPSL-CM5A coupled model: impact of the LMDZ atmospheric grid configuration, Clim. Dynam., submitted, 2012. 
Jost, A., Lunt, D., Kageyama, M., Abe-Ouchi, A., Peyron, O., Valdes, P., and Ramstein, G.: High-resolution simulations of the last glacial maximum climate over Europe: a solution to discrepancies with continental palaeoclimatic reconstructions?, Clim. Dynam., 24, 577-590, 2005.

Jost, A., Fauquette, S., Kageyama, M., Krinner, G., Ramstein, G., Suc, J.-P., and Violette, S.: High resolution climate and vegetation simulations of the Late Pliocene, a model-data comparison over western Europe and the Mediterranean region, Clim. Past, 5, 585-606, doi:10.5194/cp-5-585-2009, 2009.

Kamae, Y., Ueda, H., and Kitoh., A.: Hadley and Walker circulations in the mid-Pliocene warm period simulated by an atmospheric general circulation model, J. Meteor. Soc. Jpn., 89, 475493, 2011.

Kasahara A.: Computational aspects of numerical models for weather prediction and climate simulation, in: Methods in computational physics, edited by: Chang, J., Academic, Amsterdam, 17, 1-66, 1977.

Koenig, S. J., DeConto, R. M., and Pollard, D.: Pliocene Model Intercomparison Project Experiment 1: implementation strategy and mid-Pliocene global climatology using GENESIS v3.0 GCM, Geosci. Model Dev., 5, 73-85, doi:10.5194/gmd-5-732012, 2012.

Krinner, G., Viovy, N., de Noblet-Ducoudre, N., Ogee, J., Polcher, J., Friedlingstein, F., Ciais, P., Sitch, S., and Prentice, I. C.: A dynamic global vegetation model for studies of the coupled atmosphere-biosphere system, Global Biogeochem. Cy., 19, GB1015, doi:10.1029/2003GB002199, 2005.

Krinner, G., Lézine, A.-M., Braconnot, P., Sepulchre, P., Ramstein, G., Grenier, C., and Gouttevin, I.: A reassessment of lake and wetland feedbacks on the North African Holocene climate, Geophys. Res. Lett., 39, L07701, doi:10.1029/2012GL050992, 2012.

Le Sommer, J., Penduff, T., Theetten, S., Madec, G., and Barnier, B.: How momentum advection schemes influence currenttopography interactions at eddy permitting resolution, Ocean Model., 29, 1-14, doi:10.1016/j.ocemod.2008.11.007, 2009.

Leduc G., Schneider, R., Kim, J.-H., and Lohmann, G.: Holocene and Eemian sea surface temperature trends as revealed by alkenone and $\mathrm{Mg} / \mathrm{Ca}$ paleothermometry, Quat. Sci. Rev., 29, 989-1004, 2010.

Lévy, M., Estublier, A., and Madec, G.: Choice of an advection scheme for biogeochemical models. Geophys. Res. Lett., 28, 3725-3728, doi:10.1029/2001GL012947, 2001.

Lott, F.: Alleviation of Stationary Biases in a GCM through a Mountain Drag Parameterization Scheme and a Simple Representation of Mountain Lift Forces, Mon. Weather Rev., 127, 788-801, doi:10.1175/1520-0493(1999)127<0788:AOSBIA > 2.0.CO;2, 1999.

Lott, F., Fairhead, L., Hourdin, F., and Levan, P.: The stratospheric version of LMDz: dynamical climatologies, arctic oscillation, and impact on the surface climate, Clim. Dynam., 25, 851-868, 2005.

Madec, G.: NEMO ocean engine. Technical note, IPSL, available at: http://www.nemo-ocean.eu/About-NEMO/Reference-manuals, NEMO_book_v3_4.pdf (last access: 22 May 2012), 2008.
Madec, G. and Imbard, M.-A.: global ocean mesh to overcome the North Pole singularity, Clim. Dynam., 12, 381-388, 1996.

Madec, G., Delecluse, P., Imbard, M., and Levy, C.: OPA version 8.1 Ocean general circulation model reference manual, 3. LODYC, Technical Report, 91 pp., available at: http://www.nemo-ocean.eu/About-NEMO/Reference-manuals, Doc_OPA8.1 (last access: 22 May 2012), 1997.

Marti O., Braconnot, P., Dufresne, J.-L., Bellier, J., Benshila, R., Bony, S., Brockmann, P., Cadule, P., Caubel, A., Codron, F., de Noblet, N., Denvil, S., Fairhead, L., Fichefet, T., Foujols, M.A., Friedlingstein, P., Goosse, H., Grandpeix, J.-Y., Guilyardi, E., Hourdin, F., Krinner, G., Lévy, C., Madec, G., Mignot, J., Musat, I., Swingedouw, D., and Talandier, C.: Key features of the IPSL ocean atmosphere model and its sensitivity to atmospheric resolution, Clim. Dynam., 34, 1-26, doi:10.1007/s00382-009-06406, 2010.

Morcrette, J.: Radiation and cloud radiative properties in the European Centre for Medium Range Weather Forecasts forecasting system, J. Geophys. Res., 96, 9121-9132, 1991.

Murray, R. J.: Explicit generation of orthogonal grids for ocean models, J. Comput. Phys., 126, 251-273, 1996.

Ramstein, G., Serafini-Le Treut, Y., Le Treut, H., Forichon, M., and Joussaume, S.: Cloud processes associated with past and future climate changes, Clim. Dynam., 14, 233-247, 1998.

Ravelo, A. C., Andreasen, D. H., Lyle, M., Lyle, A. O., and Wara, M. W.: Regional climate shifts caused by gradual global cooling in the Pliocene epoch, Nature, 429, 263-267, 2004.

Reynolds, R. W. and Smith, T. M.: A high resolution global sea surface temperature climatology, J. Climate, 8, 1571-1583, 1995.

Robinson, M. M., Dowsett, H. J., Dwyer, G. S., and Lawrence, K. T.: Reevaluation of mid-Pliocene North Atlantic sea surface temperatures, Paleoceanography, 23, PA3213, doi:10.1029/2008PA001608, 2008.

Sadourny, R. and Laval, K.: January and July performance of the LMD general circulation model, in: New perspectives in climate modeling, edited by: Berger, A. and Nicolis, C., Elsevier, Amsterdam, 173-197, 1984.

Salzmann, U., Haywood, A. M., Lunt, D. J., Valdes, P. J., and Hill, D. J.: A new global biome reconstruction and data-model comparison for the Middle Pliocene, Global Eco. Biogeogr., 17, 432447, 2008.

Salzmann, U., Haywood, A. M., and Lunt, D. J.: The past is a guide to the future? Comparing Middle Pliocene vegetation with predicted biome distributions for the twenty-first century, Phil. Trans. R. Soc. A, 367, 189-204, 2009.

Sitch, S., Smith, B., Prentice, C., Arneth, A., Bondeau, A., Cramer, W., Kaplan, J. O., Levis, S., Lucht, W., Sykes, M. T., and Thonicke, K.: Evaluation of ecosystem dynamics, plant geography and terrestrial carbon cycling in the LPJ dynamic vegetation model, Glob. Change Biol., 9, 161-185, 2003.

Sloan, L. C., Crowley, T. J., and Pollard, D.: Modeling of middle Pliocene climate with the NCAR 25 GENESIS general circulation model, Mar. Micropaleontol., 27, 51-61, 1996.

Sohl, L. E., Chandler, M. A., Schmunk, R. B., Mankoff, K., Jonas, J. A., Foley, K. M., and Dowsett, H. J.: PRISM3/GISS topographic reconstruction, US Geol. Surv. Data Series, 419, 6 pp., 2009. 
Valcke, S.: OASIS3 user guide (prism 2-5), PRISM report no 2. Tech. Rep. TR/CMGC/06/73, CERFACS, Toulouse, France, 60 pp., 2006.

Yan, Q., Zhang, Z. S., Wang, H. J., Gao, Y. Q., and Zheng, W. P.: Set-up and preliminary results of mid-Pliocene climate simulations with CAM3.1, Geosci. Model Dev., 5, 289-297, doi:10.5194/gmd-5-289-2012, 2012.
Zhang, Z. S., Nisancioglu, K., Bentsen, M., Tjiputra, J., Bethke, I., Yan, Q., Risebrobakken, B., Andersson, C., and Jansen, E.: Pre-industrial and mid-Pliocene simulations with NorESM-L, Geosci. Model Dev., 5, 523-533, doi:10.5194/gmd-5-523-2012, 2012. 